\title{
Income and Social Determinants of Old-Age Savings: Evidence from Poland
}

\author{
Sylwia Pieńkowska-Kamieniecka, PhD \\ University of Warmia and Mazury in Olsztyn, Poland
}

Damian Walczak, PhD

Nicolaus Copernicus University in Torun, Poland

Corresponding Author

Anna Bera

University of Szczecin, Poland

Doi: 10.36941/ajis-2019-0023

\begin{abstract}
The aim of the article is to determine the impact of social determinants on saving for old age with regards to income. The study presents two models of logistic regression. The first one includes only social determinants of family members among independent variables, while the second one includes also income. The results of logistic regression in the model excluding income showed that such variables as gender, age, years of education, place of residence or number of household members have a significant impact on saving for old age. Moreover, another conclusion drawn from the results is that after including income in the model (which turned out to be statistically significant) almost all social determinants remain significant. Therefore, income is a significant variable which affects the odds ratio of owning old-age savings by a household, so financial determinants are important, when we want to study the level of savings. The research presented in the article comes from the representative nationwide study the Social Diagnosis which was conducted among 11,740 households in Poland in 2015.
\end{abstract}

Keywords: old age; savings; income; household head

\section{Introduction}

Savings constitute a very important aspect of how households function and impact on their current and future financial situation. Their character may be general, i.e. have no special purpose, or targeted. In the second case, one of the key saving goals is financial security for old age. Many previous empirical studies indicate that various determinants affect people's behavior, including their willingness to save for old age. In literature, the role of both social and economic determinants is stressed (Popa, 2012; van Erp, Vermeer \& van Vuuren, 2013; Kolasa \& Liberda, 2014; Sass 2016; Cynamon \& Fazzari, 2017).

The subject of additional saving for old age is an important and on-going issue. Poland is one of the fastest ageing countries in the European Union. The old age dependency ratio (people aged $65+$ as $\%$ of the population aged 15-64) is to grow from $23.7 \%$ in 2016 up to $55.3 \%$ in 2050 (European Commission 2017). Moreover, in light of the lowered retirement age since October 2017 (to 60 years for women and 65 for men from the level of 67 years for both groups), longer life will 
increase the number of years of pension entitlement in relation to years of contribution periods, which in turn will result in lower pension rates. In effect, a greater part of Polish society will obtain lower pensions. This results from the change in the formula regarding pension calculation, i.e. deviation from defined benefit in favour of defined contribution (Chłoń-Domińczak \& Strzelecki, 2013). Consequently, new pensions to a greater extent will be determined by contribution periods and longer life expectancy (World Bank Group, 2017).

The European Commission estimated that net theoretical replacement rate (net TRR), with an assumption of 40 years' uninterrupted career, ending with the standard retirement age, in 2016 in Poland reached on average 85.9 for men and 73.0 for women. Nonetheless, by 2056, TRR will have lowered and reach 44.9 for men and 31.9 for women (European Commission, 2018). This will be one of the highest drops of net TRR in the European Union (right after Romania), which will be the result of lowering the standard retirement age in 2017 mentioned above.

One of the possibilities to increase the pension rate is the accumulation of additional savings which will be used in the period after the ending of a career. In Poland there are three institutionalised forms of additional voluntary saving for old age: individual pension accounts, individual pension security accounts, and employee pension schemes. Evidently, voluntary savings should play a greater role in securing adequate benefits for old age (European Commission, 2012). However, according to the data of the Polish Financial Supervision Authority (pl. Komisja Nadzoru Finansowego, KNF), only $5.5 \%$ of workers save individually in additional programs (individual pension accounts), $3.9 \%$ use individual pension security accounts while only $2.4 \%$ participate in employee pension schemes.

Savings for old age (apart from the public system) are affected mainly by decisions made by household heads. Their characteristics seem the most significant while analysing the financial situation and behaviours, including saving, of households. Analysing the financial situation and the management of household budgets by studying the characteristics of a household head has been used in numerous studies worldwide (Lusardi \& Mitchell, 2008; Devlin-Foltz, Henriques \& Sabelhaus, 2015; Corneo, Schröder \& König, 2015; Rhee \& Boivie, 2015).

The results of the study indicate that gender is one of the most important social determinants, which impacts on saving for old age (Bashir et al., 2013; Tan, Folk \& Choong, 2012). The gender of a household head determines the size of household savings (Pieńkowska-Kamieniecka, 2017; Walczak \& Pieńkowska-Kamieniecka, 2018). Men are generally more willing to save for old age (Fernández-López, Vivel-Búa, Otero-González \& Durán-Santomil, 2015). Gifford \& Nilsson (2014) consider religion as one of the social determinants. According to Sablosky (2014) and Su, Chou, and Osborne (2011), religiosity impacts significantly on financial decisions. According to Love (2010), marital status has important effects on household decisions, including financial ones. Since a person who is single does not have so many duties or dependents, they can take financial risk (Ayuub et al., 2015). Shivapour et al. (2012) stress the significant impact of income and education on financial decisions. On the other hand, Folk, Beh, and Baranovich (2012) have pointed out that better educated people save more, whereas Lown et al. (2015) and Ozcan, Gunay, and Ertac (2003) determined the impact of age and income on the amount of savings. Moreover, volunteers enjoy better mental health and, therefore, they are more engaged and rational about making all decisions, including the financial ones (van Ingen \& Wilson, 2017).

In addition, according to Le Blanc et al. (2016), the most frequent motives of saving include precautionary saving and saving for old-age. The present article focuses on the second motive. The aim of the article is to determine the impact of social determinants on saving for old age with regards to income.

Thus, the following hypotheses were assumed:

Hypothesis 1: Income of the household head has a significant impact on old-age savings owned by a household.

Hypothesis 2: Social determinants also have an impact on old-age saving decisions in a household.

The paper is comprised of five sections. Section 1 contains an introduction which outlines the premises and the necessity of additional saving for old age in Poland as well as factors which in the light of various studies conducted worldwide have impact on additional old age saving. Section 2 
presents the methodology of the research, including participants, measures and data analysis. Section 3 contains the results of the two regression models whereas Section 4 discusses the empirical findings of the conducted research in relation to other studies worldwide. Finally, Section 5 constitutes a concluding part of the paper.

\section{Methodology}

\subsection{Participants and Procedure}

The article presents data from representative nationwide study the Social Diagnosis (the data used in this study is publicly available), conducted within the whole area of Poland in March 2015 (Social Diagnosis 2015). Its concept was designed by the Social Monitoring Council while field studies were conducted by professional interviewers from the Central Statistical Office in Poland. The study provides significant information regarding economic (e.g. income, savings) and non-economic aspects (e.g. education, participation in social life, religious practices, care for family, essential values in life) of households as well as attitudes and behaviors of their members. It constitutes a diagnosis of life quality and living conditions of Poles from their own perspective (Panek, Czapiński \& Kotowska, 2015). 11,740 households took part in the study Social Diagnosis 2015 (Czapiński \& Panek, 2015). The article presents data concerning 7,433 households which in the study answered the question whether they accumulate savings for old age (5,093-No; 2,340-Yes). In the case of the remaining 4,307 households, there was no reply. The subject of the study in each household was the person with the greatest knowledge regarding their financial situation, who makes major decisions for the household. This person is further referred to as the household head.

\subsection{Measure}

To realize the research objectives, the method of logistic regression was used (Hosmer, Lemeshow \& Sturdivant, 2013). While constructing logistic regression models in the article, the following dependent variable was adopted: $Y$ - owning of old-age savings by a household.

Logistic regression is used in the case of a dichotomous response variable. The dependent variable in the model above had a dichotomous character, i.e. zero-one. This variable took on the following form:

$$
Y=\left\{\begin{array}{c}
1, \text { in the case that the event happened } \\
0 \text {, otherwise }
\end{array}\right.
$$

Independent variables may be qualitative as well as quantitative. Having in mind the aim and research hypotheses, two models of logistic regression were constructed for the dependent variable specified as owning old-age savings by a household. In Model 1 (M1) only social determinants affecting old-age savings were analysed, excluding income. In turn in Model 2 (M2), which took into consideration economic determinants, income was one of the independent variables.

The characteristics of independent variables used in the models are presented in Table 1. For each qualitative variable a reference group was specified and included in the analysis.

Table 1: Descriptive statistics for the independent variables

\begin{tabular}{|c|c|c|c|c|}
\hline Variable & Variable description & Nature of the variables & $\mathrm{N}$ & $\begin{array}{c}\text { Other } \\
\text { characteristics }\end{array}$ \\
\hline \multicolumn{5}{|c|}{ Qualitative variables } \\
\hline \multirow[t]{2}{*}{ Gender } & Gender & Women (ref. group ${ }^{1}$ ) & 2.349 & $31.6 \%$ \\
\hline & & Men & 5.082 & $68.4 \%$ \\
\hline \multirow{3}{*}{$\begin{array}{l}\text { Place of } \\
\text { residence }\end{array}$} & Place of residence & Rural areas (ref. group) & 2.936 & $39.5 \%$ \\
\hline & & City or town (more than & & \\
\hline & & 5,000 inhabitants) & 4.497 & $60.5 \%$ \\
\hline \multirow[t]{4}{*}{ Marital status } & Marital status & Singles (ref. group) & 722 & $9.7 \%$ \\
\hline & & Married & 5.029 & $67.9 \%$ \\
\hline & & Widow/widower & 1.170 & $15.8 \%$ \\
\hline & & Divorced/separated & 485 & $6.5 \%$ \\
\hline
\end{tabular}




\begin{tabular}{|c|c|c|c|c|}
\hline \multirow[t]{2}{*}{ Meaning of life } & What, in your opinion, is more important in life? & $\begin{array}{l}\text { Pleasures and lack of } \\
\text { stress (ref. group) }\end{array}$ & 2.151 & $35.0 \%$ \\
\hline & & $\begin{array}{l}\text { Sense of purpose and } \\
\text { goal achievement }\end{array}$ & 3.989 & $65.0 \%$ \\
\hline \multirow[t]{2}{*}{ Work } & Do you think work is the most important condition of a & No (ref. group) & 4.304 & $71.2 \%$ \\
\hline & happy life? & Yes & 1.740 & $28.8 \%$ \\
\hline Volunteering & $\begin{array}{l}\text { Did you perform unpaid work or offer services for non- } \\
\text { family or local community members in the last year? }\end{array}$ & $\begin{array}{l}\text { No (ref. group) } \\
\text { Yes, often } \\
\text { Yes, rarelv }\end{array}$ & $\begin{array}{c}4.258 \\
563 \\
1324\end{array}$ & $\begin{array}{c}63.3 \% \\
9.2 \% \\
21.5 \%\end{array}$ \\
\hline \multirow[t]{4}{*}{ Care } & Did you feel responsible for taking care of and the & Often (ref. group) & 723 & $11.8 \%$ \\
\hline & good well-being of parents or elderly relatives in the & Sometimes & 1.728 & $29.1 \%$ \\
\hline & past few months? & Never & 905 & $14.8 \%$ \\
\hline & & N/A & 2.723 & $44.4 \%$ \\
\hline Dependence on & Does your evaluation of the previous year as & No (ref. group) & 5.654 & $94.7 \%$ \\
\hline government & successful/unsuccessful depend on the government? & Yes & 317 & $5.3 \%$ \\
\hline Dependence on & Does your evaluation of the previous year as & No (ref. group) & 1.505 & $24.8 \%$ \\
\hline myself & successful/unsuccessful depend on your actions only? & Yes & 4.507 & $75.2 \%$ \\
\hline \multicolumn{5}{|c|}{ Quantitative variables } \\
\hline Age & Age in 2015 & Years & \multicolumn{2}{|c|}{$\begin{array}{l}\text { 7.433 Mean 56.5; Min. } \\
\text { 19; Max. } 100\end{array}$} \\
\hline Education & Number of years of education & Years & \multicolumn{2}{|c|}{$\begin{array}{l}\text { 7.423 Mean 12.5; Min. 1; } \\
\text { Max. } 26\end{array}$} \\
\hline $\begin{array}{l}\text { Number of } \\
\text { people }\end{array}$ & Number of household members & Number & \multicolumn{2}{|c|}{$\begin{array}{l}\text { 7.432 Mean 2.9; Min. 1; } \\
\text { Max. } 14\end{array}$} \\
\hline Church & $\begin{array}{l}\text { On average, how often in a month do you take part in a } \\
\text { church service or other religious meetings? }\end{array}$ & Number/month & \multicolumn{2}{|c|}{$\begin{array}{l}\text { 6.149 Mean 2.8; Min. 0; } \\
\text { Max. } 35\end{array}$} \\
\hline Reading press & How many hours weekly do you read the press? & Hours/week & \multicolumn{2}{|c|}{$\begin{array}{l}\text { 6.129 Mean 3.2; Min. 0; } \\
\text { Max. } 90\end{array}$} \\
\hline Income & $\begin{array}{l}\text { What is your average monthly net income in the last } \\
\text { three months? }\end{array}$ & PLN/3 months & \multicolumn{2}{|c|}{$\begin{array}{l}\text { 5.356 Mean 2.4; Min. 0.2; } \\
\text { Max. } 30.0\end{array}$} \\
\hline
\end{tabular}

Source: own study based on (Social Diagnosis, 2015).

\subsection{Data Analysis}

The choice of variables for the logistic regression models was made using Wald's backward elimination method, i.e. stepwise regression (significance level to stay in the models was 0.05). Variables with all statistically insignificant categories were removed. The verification of the validity of the models examined in the article was performed using the Hosmer-Lemeshow test (Hosmer, Lemeshow \& Sturdivant, 2013). High values of the Hosmer-Lemeshow test and the fact that the variables were statistically significant allow the conclusion that the models are correct, i.e., they successfully went through the verification and they are reliable.

\section{Results}

The results of the logistic regression models are presented in Table 2. Such variables as gender, age, place of residence, education, number of household members, volunteering, dependence on government and reading the press have a significant impact on old-age savings owned by a household. They are significant in Model 1 (without the income variable) and Model 2 (including income as one of the dependent variables).

What is more, in both models, as a consequence of statistical insignificance, the following variables were removed: marital status, meaning of life, work as a condition of a happy life, care for parents or elderly relatives, and taking part in a church service or other religious meetings.

The results of the study indicate that among all social variables gender requires special attention in reference to its impact on saving for old age. In male-headed households, the odds ratio of owning old-age savings is higher than in female-headed households, both in Model 1 (by 38.4\%) and Model 2 (by 32.0\%). The situation is similar in the case of age. Increasing age of the person making key financial decisions in a household raises the odds ratio of owning old-age savings by 
$3.5 \%$ in Model 1 and by $3.7 \%$ in Model 2. Also, every additional year of education that the head of a household has increases the odds ratio of owning such savings, but more strongly in Model 1, i.e. by $6.7 \%$ (when income is not taken into account), than in Model 2 (when income is one of the variables), i.e. by $4.1 \%$. Saving for old age is also positively influenced by reading the press. A greater number of hours (by one in one week) spent on reading the press (by a head of the household) increases the odds ratio of owned savings for old age correspondingly in both models (i.e. by approximately $2 \%$ ). Additionally, the number of people in a household has a negative impact on owning savings. With every additional household member the odds ratio of owning savings decreases: in Model 2 by $9.0 \%$, and by $6.1 \%$ in Model 1 , where the odds ratio is lower when we exclude the variable of income from the analysis. The decision-making process considered in the study is also affected by household heads' reliance on government actions. It turns out that when household heads base their decision-making process concerning their socio-economic situation on government actions, the odds ratio of having savings for old age in the household is lower by $28.1 \%$ (M1) and $28.5 \%$ (M2).

Also, performing unpaid work or offering services for others have a significant impact on saving. The odds ratio of owning savings for old age by individuals who often help others is higher by $20.0 \%$ (M1) and $22.2 \%$ (M2) accordingly as compared to those who do not engage in helping others. In the case of individuals who engage in help rarely, the odds ratio is higher by $17.3 \%$ (M1) and $18.7 \%(\mathrm{M} 2)$.

Living in a city or town increases the odds ratio of saving for old age (by $14.1 \%$ when compared to living in the rural areas), yet only in model M1, which excludes the variable of income. Another statistically significant variable only in one model (M1) is conditioning one's success in life on oneself, not on others. If the household head claims that their evaluation of the previous year as successful depends only on their actions, the odds ratio of owning savings for old age is higher by $16.2 \%$. However, this variable is statistically insignificant in the model which includes income (M2).

It needs to be stressed that income as one of the dependent variables (M2) is statistically significant. When the income of the household head is higher by 1 thousand PLN, the odds ratio of owning savings for old age by a particular household is higher by $18.3 \%$.

Table 2: Estimates of logistic regression models without income (Model 1) and with income (Model 2) after backward selection of variables for 'household's old-age savings'

\begin{tabular}{|c|c|c|c|c|c|c|}
\hline \multirow{2}{*}{ Variable } & \multicolumn{3}{|l|}{ M1 } & \multicolumn{3}{|l|}{ M2 } \\
\hline & The significance level & S.E. & $\operatorname{Exp}(B)$ & The significance level & S.E. & $\operatorname{Exp}(B)$ \\
\hline Gender (base = women) & $.000^{* * *}$ & .066 & 1.384 & $.000^{\star * *}$ & .072 & 1.320 \\
\hline Age & $.000^{* * *}$ & .002 & 1.035 & $.000^{* * *}$ & .003 & 1.037 \\
\hline Place of residence (base = rural areas) & $.046^{*}$ & .066 & 1.141 & - & - & - \\
\hline Education & $.000^{* * *}$ & .010 & 1.067 & $.000^{* * *}$ & .011 & 1.041 \\
\hline Number of people & $.006^{* *}$ & .023 & .939 & $.000^{* * *}$ & .025 & .910 \\
\hline Volunteering (base = no) & $.038^{*}$ & & & $.037^{*}$ & & \\
\hline Yes, often & .072 & .102 & 1.200 & .066 & .109 & 1.222 \\
\hline Yes, rarely & $.031^{*}$ & .074 & 1.173 & $.031^{*}$ & .080 & 1.187 \\
\hline Dependence on government (base $=$ no) Yes & $.019^{*}$ & .141 & .719 & $.028^{*}$ & .153 & .715 \\
\hline Dependence on myself (base $=$ no) Yes & $.030^{*}$ & .069 & 1.162 & - & - & - \\
\hline Reading press & $.001^{* * *}$ & .007 & 1.024 & $.006^{\star *}$ & .008 & 1.021 \\
\hline Income & $x$ & $x$ & $x$ & $.000^{* * *}$ & .022 & 1.183 \\
\hline Const. & $.000^{* * *}$ & .257 & .020 & $.000^{* * *}$ & .272 & .022 \\
\hline $\mathrm{N}$ & 5.834 & & & 5.074 & & \\
\hline Cox-Snell's R-squared & .065 & & & .076 & & \\
\hline Nagelkerke's R-squared & .091 & & & .107 & & \\
\hline Log likelihood & $6,926.244$ & & & $5,956.413$ & & \\
\hline Chi-square & 12.339 & & & 14.729 & & \\
\hline Hosmer-Lemeshow ( $p$-value) & .137 & & & .065 & & \\
\hline
\end{tabular}

Source: own study based on (Social Diagnosis 2015). 


\section{Discussion}

Our study confirms the results of numerous studies which indicate that a significant determinant having impact on old-age savings is the level of income (Goda, Manchester \& Sojourner, 2013; Grigorescu, Oprisan \& Condrea, 2017). Households with higher income display a greater willingness to save (Alvarez-Cuadrado \& El-Attar Vilalta, 2012). In addition we pointed out that, irrespective of income, other social determinants of the household head also have an impact on having savings for old age, like gender. As in other studies, men are more concerned than women about financial issues. Consequently, male-headed households are also more willing to save for old age (Taft et al., 2013). There is evidence that men and women differ in their attitude to risk (Clark, Strauss \& Knox-Hayes, 2012; Likitapiwad, Sereetrakul \& Wongveeravuti, 2013; Fadila \& Alam, 2016). Men are more risk tolerant than women, who are more conservative while making financial decisions (Rietjens, 2011). Moreover, women are less likely to claim that planning for retirement is necessary at all (Clark, Strauss \& Knox-Hayes, 2012). As a result, our research confirms that gender of a household head has impact on savings for old age owned by a particular household.

Besides, important are also age and education of the household head. Elderly people think of retirement more often, so households near retirement save adequately (Campbell \& Weinberg, 2015). Also, according to the results of the study by Rhee and Boivie (2015), there is a gap between older and younger households in retirement savings. Our findings seem to support also the traditional view that more educated people save more (Lusardi, 2016). Higher education means greater knowledge, including financial competence. Reading the press and other financial literature results in a higher level of knowledge and financial literacy and is the basis of effective functioning in the modern developed society (Starček \& Trunk, 2016).

Taking into consideration the location of a household it needs to be stressed that the differences between households in urban and rural locations with regard to the odds ratio of owning old-age savings occur while analysing only social determinants. If the analysis includes income, it turns out that this variable is not statistically significant. As a result, our studies do not confirm conclusions from the research by Vaillancourt et al. (2015) according to which rural households have in general lower costs of living and, therefore, they need a smaller amount of retirement savings than urban households. Nonetheless, it needs to be taken into consideration that the majority of inhabitants of rural areas in Poland receive a pension from the agricultural system. These pensions are notably lower than from the common system of social insurance (Walczak, 2017).

Our research also shows that household size affects owned savings negatively. A larger number of household members increases basic consumption needs of a household (Capéau \& De Rock, 2015) and consequently reduces its saving capability. For example the study of Scholz \& Seshadri (2007) also shows that, in particular, households with children have lower mean net worth than childless households.

Numerous studies stress that retirement planning is the predictor of wealth accumulation for old age. Individuals who do not think of retirement have lower willingness to save for old age (Tan, Folk \& Choong, 2012). The retirement planning is also connected with the concept that the State should guarantee, inter alia, suitable pensions (Esping-Andersen, 2013). Individuals who make their lives and the situation of their household dependent on the State have a higher odds ratio of owning savings for old-age.

Unlike some previous researchers (e.g., Gonzalez \& Özcan, 2013; Beckmann, Hake \& Urvova, 2013), we did not show that married people save more. In our research this variable is not statistically significant. Schreiner \& Sherraden (2007) also show, unlike our research, that divorced, separated or widowed people save for retirement like never-married (single) people.

\section{Conclusions}

The aim of the article was to determine the impact of social determinants on saving for old age with regard to income. It seems highly important in the light of lowering level of benefits from the public pension system in Poland. These benefits will not allow future pensioners to maintain their 
standard of living from their career period. As a result, it is necessary to save additionally for old age and retirement.

Analysis of two models of logistic regression resulted in a positive verification of research hypotheses of the paper. The results indicate that the income of the household head has a significant impact on old-age savings owned by a household. Nonetheless, social determinants also have an impact on old-age saving decisions in a household. It is visible in both the model of logistic regression which does not include income as an independent variable, as well as in the model including income. This constitutes proof that income (despite its significance) is not the most important factor determining the odds ratio and the scale of savings for old age. The results clearly show that it is equally important to take into consideration the social determinants of the household head presented in the paper.

Such an approach to studying social determinants which condition savings for old age in a particular household is unique and has not been conducted in Poland, a EU member state with a population of 38 million, so far.

However, this study has some limitations. The dependent variables used in the models of logistic regression present only the odds ratio of owning old-age savings, not the amount of savings, which was not the subject of the Social Diagnosis study. For this reason, analyses presented in the paper could concern only the aforementioned determinants which positively impact on the value of owned old age savings by a particular household in Poland. However, it is a correct approach as similar studies have been conducted in many other countries.

\section{References}

Alvarez-Cuadrado, F., \& El-Attar Vilalta, M. (2012). Income Inequality and Saving. IZA Discussion Paper 7083, $1-30$.

Ayuub, M. S., Saleem, H.M.N., Latif, M., \& Aslam, M. (2015). Financial Risk Tolerance Based On Demographic Factors: Pakistani Perspective. International Journal of Information, Business and Management, 7, 226.

Bashir, T., Hassan, A., Nasir, S., Baber, A., \& Shahid, W. (2013). Gender Differences in Saving Behavior and its Determinants: Patron from Pakistan. IOSR Journal of Business and Management, 9(6), 75.

Beckmann, E., Hake, M., \& Urvova, J. (2013). Determinants of Households Savings in Central, Eastern and Southeastern Europe. Focus on European Economic Integration, Q3/13, 8-29.

Campbell, D., \& Weinberg. J.A. (2015). Are We Saving Enough? Households and Retirement. Economic Quarterly, 101(2), 102. http://doi.org/10.21144/eq1010202

Capéau, B., \& De Rock, B. (2015). The implications of household size and children for life-cycle saving. Working Paper Research, 286, 2.

Chłoń-Domińczak, A., \& Strzelecki, A. P. (2013). The minimum pension as an instrument of poverty protection in the defined contribution pension system-an example of Poland. Journal of Pension Economics \& Finance, 12(3), 326-350.

Clark, G.L., Strauss, K., \& Knox-Hayes, J. (2012). Saving for Retirement. Intention, Context and Behavior. Oxford University Press, 65, 67.

Corneo, G., Schröder, C., \& König, J. (2015). Distributional Effects of Subsidizing Retirement Savings Accounts: Evidence from Germany. Discussion Paper. Economics, 18.

Cynamon, B.Z., \& Fazzari, S.M. (2017). Household income, demand, and saving: deriving macro data with micro data concepts. Review of Income and Wealth, 63, 53-69. DOI:10.1111/roiw.12206

Czapiński, J., \& Panek, T. (2015). Social Diagnosis 2015. Objective and subjective quality of life in Poland, Contemporary Economics. Quarterly of University of Finance and Management in Warsaw, 9,14-15, DOI:10.5709/ce.1897-9254.176. DOI:10.5709/ce.1897-9254.176

Devlin-Foltz, S., Henriques, A.M., \& Sabelhaus, J. (2015). The evolution of retirement wealth. Finance and Economics Discussion Series 2015-009. http://dx.doi.org/10.17016/FEDS.2015.009

Esping-Andersen, G. (2013). The three worlds of welfare capitalism. Cambridge: John Wiley \& Sons.

European Commission. (2012). White Paper. An Agenda for Adequate, Safe and Sustainable Pensions. Brussels, 12.

European Commission. (2017). The 2018 Ageing Report. Underlying Assumptions \& Projection Methodologies. Institutional Paper 065. Brussels: European Union.

European Commission. (2018). Pension Adequacy Report 2018. Current and Future Income Adequacy in Old Age in the EU, Vol. 1. Brussels: European Union.

Fadila, D.E.S., \& Alam, R.R. (2016). Factors affecting adjustment to retirement among retirees' elderly persons. Journal of Nursing Education and Practice, 6, 118. DOI: 10.5430/jnep.v6n8p112 
Fernández-López, S., Vivel-Búa, M., Otero-González, L., \& Durán-Santomil, P. (2015). Exploring the gender effect on Europeans' retirement savings. Feminist Economics, 21, 118-150. http://dx.doi.org/10.1080/13545701.2015.1005653

Folk, J.Y., Beh, L.S., \& Baranovich, D.L. (2012). Financial education: Determinant of retirement planning in Malaysia. E3 Journal of Business Management and Economics, 3, 69-78.

Gifford, R. \& Nilsson, A. (2014). Personal and social factors that influence pro-environmental concern and behaviour: A review. International Journal of Psychology, 49, 141. DOI: 10.1002/ijop.12034

Goda, G.S., Manchester, C.F., \& Sojourner, A. (2013). Do income projections affect retirement saving?. Center for Retirement Research at Boston College, 13-4, 1-7.

Gonzalez, L., \& Özcan, B. (2013). The Risk of Divorce and Household Saving Behavior. Journal of Human Resources, 48, 404-434. DOI: 10.3368/jhr.48.2.404

Grigorescu, A., Oprisan, O., \& Condrea, E. (2017). Other economico-social factors of the saving process. Holistica, 8(2), 41-48. DOI: :10.1515/hjbpa-2017-0011

Hosmer, D.W., Lemeshow, S., \& Sturdivant, R.X. (2013). Applied logistic regression, New York: John Wiley \& Sons.

Kolasa, A., \& Liberda, B. (2014). Determinants of Saving in Poland: Are They Different in Other OECD Countries?. Working Paper, 13, 3-4, http://www.wne.uw.edu.pl/inf/wyd/WP/WNE_WP130.pdf

Le Blanc, J., Porpiglia, A., Teppa, F., Zhu, J., \& Ziegelmeyer, M. (2016). Household saving behaviour in the Euro Area. International Journal of Central Banking, 12, 15-69.

Likitapiwad, T., Sereetrakul, W., \& Wongveeravuti, S. (2013). Gender differences in saving and spending behaviours Thai students. Research in Euducation, 90, 68-82. http://dx.doi.org/10.7227/RIE.90.1.5

Love, D.A. (2010). The effects of marital status and children on savings and portfolio choice. Review of Financial Studies, 23, 385-432. https://doi.org/10.1093/rfs/hhp020

Lown, J. M., Kim, J., Gutter, M.S., \& Hunt, A.T. (2015). Self-efficacy and savings among middle and low income households. Journal of Family and Economic Issues, 36, 491-502. DOI: 10.1007/s10834-014-9419-y

Lusardi, A., \& Mitchell, O.S. (2008). Planning and financial literacy: How do women fare?. American Economic Review, 98 (2), 413-17. Doi:10.1257/aer.98.2.413

Lusardi, A. (2016). Financial Literacy around the World: Evidence, Theory, and Implications. GFLEC, http://gflec.org/wp-content/uploads/2016/09/Presentation-Lusardi-Cambridge-v5.pdf

Ozcan, K. M., Gunay, A., \& Ertac, S. (2003). Determinants of private savings behaviour in Turkey. Applied Economics, 35(12), 1405-16. https://doi.org/10.1080/0003684032000100373

Panek, T., Czapiński, J., \& Kotowska, E. (2015). The research method. Social Diagnosis 2015, The Objective and Subjective Quality Of Life In Poland. Contemporary Economics, 9(5), 24-33. DOI:10.5709/ce.18979254.178

Pieńkowska-Kamieniecka, S. (2017). Gender differences in saving for retirement. Proceedings of the 14th International Scientific Conference. European Financial Systems, Part 2, 167, https://is.muni.cz/do/econ/sborniky/70896034/EFS2017-Proceedings_2_final.pdf

Popa, A. (2012). The Impact of Social Factors on Economic Growth: Empirical Evidence for Romania and European Union Countries. Romanian Journal of Fiscal Policy, 3(2), 1-16.

Rhee, N., \& Boivie, I. 2015. The Continuing Retirement Saving Crisis, http://dx.doi.org/10.2139/ssrn.2785723

Rietjens, M. (2011). Young People's Preferences for Financial versus Non-Financial Attributes of Pension Funds. Maastricht: Universiteit Maastricht.

Sablosky, R. (2014). Does religion foster generosity?. The Social Science Journal, 51, 545-53. http://dx.doi.org/10.1016/j.soscij.2014.03.012

Sass, S.A. (2016). How Do Non-Financial Factors Affect Retirement Decisions? Center for Retirement Research at Boston College, 16-3, 1-7.

Scholz, J.K., \& Seshadri, A. (2007). Children and Household Wealth. MMRC Working Paper, 2007-158, 1, http://dx.doi.org/10.2139/ssrn.1083829

Schreiner, M., \& Sherraden, M.W. (2007). Can the poor save?: saving \& asset building in individual development accounts, New Brunswick-London: Transaction Publishers,

Shivapour, S.K., Nguyen, C.M., Cole, C.A., \& Denburg, N.L. (2012). Effects of age, sex, and neuropsychological performance on financial decision-making. Frontiers in neuroscience, 682, 1-9. https://doi.org/10.3389/fnins.2012.00082

Starček, S., \& Trunk, A. (2013). The meaning and concept of financial education in the society of economic changes. [In:] Dermol, V., Trunk Š. N., Đaković, G. (ed.). Active citizenship by knowledge management \& innovation: proceedings of the Management, Knowledge and Learning International Conference. Bangkok- Celje-Lublin: ToKnowPress.

Su, H., Chou, T., \& Osborne, P. (2011). When financial information meets religion: Charitable-giving behavior in Taiwan. Social Behavior and Personality: An International Journal, 39, 1009-20. https://doi.org/10.2224/sbp.2011.39.8.1009 
Taft, M. K., Hosein, Z.Z., Mehrizi, S.M.T., \& Roshan, A. (2013). The relation between financial literacy, financial well-being and financial concerns. International Journal of Business and Management, 8, 70. http://dx.doi.org/10.5539/ijbm.v8n11p63

Tan, H.K., Folk, J.Y., \& Choong, K.F. (2012). Influence of age cohort on retirement planning. African Journal of Business Management, 6, 6623, 6625. DOI: 10.5897/AJBM12.292

Vaillancourt, F., Lammam, C., Herxog, I., \& Ebrahimi, P. (2015). Compulsory Government Pensions vs. Private Savings. The Effect of Previous Expansion to the Canada Pension Plan. Columbia: Fraser Institute.

van Erp, F., Vermeer, N., \& van Vuuren, D. (2013). Non-financial Determinants of Retirement. CPB Discussion Paper, 243, 34.

van Ingen, E., \& Wilson, J. (2017). I Volunteer, Therefore I am? Factors Affecting Volunteer Role Identity. Nonprofit and Voluntary Sector Quarterly, 461, 42-43. DOI: $10.1177 / 0899764016659765$

Walczak, D. (2017). Przywileje emerytalne - aspekt społeczno-ekonomiczny [Pension privileges - the economic and social aspects]. Studia Oeconomica Posnaniensia, 5, 55. DOI: 10.18559/SOEP.2017.10.0

Walczak, D., \& Pieńkowska-Kamieniecka, S. (2018). Gender Differences in Financial Behaviours. Inzinerine Ekonomika-Engineering Economics, 29(1), 123-132. DOI: http://dx.doi.org/10.5755/j01.ee.29.1.16400

World Bank Group. (2017). Poland: Toward a Strategic, Effective, and Accountable State. Systemic Country Diagnostic. Washington, D.C.: World Bank Group. 